Bibliotech : Jurnal Ilmu Perpustakaan dan Informasi, 3 (1) 2018

\title{
PERILAKU INFORMASI REMAJA TERHADAP VIRAL CHALLENGE DI MEDIA SOSIAL
}

\author{
Elfitri Kurnia Erza ${ }^{1^{*}}$; Rosini ${ }^{2}$ \\ 1,2 Program studi Ilmu Perpustakaan, Fakultas Teknologi Informasi, Universitas Yarsi \\ *Korespondensi: elfitri.kurnia@yarsi.ac.id
}

\begin{abstract}
ABSTRAK
Remaja dan media sosial seperti tidak bisa dipisahkan. Adanya tantangan viral sering dilakukan para remaja dan diunggah ke media sosial mereka. Penelitian ini membahas mengenai perilaku informasi remaja terhadap informasi mengenai tantangan yang sedang viral di media sosial. Populasi dalam penelitian ini adalah remaja yang pernal melakukan tantangan yang sedang viral di facebook dan Instagram. Tujuan dari penelitian ini adalah untuk melihat sejauh mana perilaku informasi remaja dalam menerima informasi mengenai tantangan yang sedang viral di media sosial. Metode penelitian yang digunakan adalah metode deskriptif untuk melihat gambaran kemudian ditarik kesimpulan secara umum. Pengumpulan data dilakukan dengan observasi, kuesioner dan studi dokumentasi. Berdasarkan hasil penelitian didapatkan bahwa para remaja mendapatkan informasi mengenai tantangan viral dari halaman utama media sosial mereka, kemudian jika mereka tertarik terhadap satu tantangan akan dilakukan penggalian informasi mengenai siapa saja yang sudah melakukan, dan bagaimana cara melakukan tantangan tersebut. Lebih dari setengah responden menyatakan tidak mengikuti tantangan yang membahayakan diri mereka, namun mereka mengikuti beberapa tantangan yang akan menganggu kesehatan mereka.
\end{abstract}

Kata kunci: tantangan viral, media sosial, remaja

\section{PENDAHULUAN}

Media sosial merupakan media yang digunakan untuk berinteraksi dengan berbasis web. Menurut Kaplan \& Haenlein (2010) media sosial memungkinkan terjadinya pertukaran informasi secara user-generated content. Dimana semua informasi yang ada di media sosial dipertkarkan dengan media audio-visual dalam berbagai platform seperti blog, komentar, halaman aplikasi dan sebagainya. Berdasarkan data Kompas (2016) bahwa dari 132 juta pengguna internet di Indonesia $95 \%$ menggunaan media sosial. Hal ini membuktikan bahwa tingginya penggunaan media sosial oleh masyakat Indonesia. Tingginya tingkat penggunaan media sosial di masyarakat tentu saja mencakup berbagai kalangan mulai dari usia anak-anak sampai tua, menengah atas sampai atas, bahkan bisa dikatakan bahwa mereka yang memiliki smartphone pasti menggunakan media sosial. 
Media sosial sudah tidak asing lagi bagi masyarakat Indonesia. Berbagai media sosial hadir mengisi kehidupan sehari-hari para penggunanya. Mulai dari twitter, instagram, path, facebook dan banyak lagi. Pengguna media sosial aktif pada tahun 2016 mencapai 132 juta orang dimana 95\% menggunakan media sosaial (Kompas, 2016). Menurut informasi yang dihimpun Kompas (2016) data pengguna facebook pada tahun 2016 adalah 88 juta orang. Hal ini cukup membuktikan kedekatan masyarakat Indonesia dengan situs jejaring sosial pertemanan.

Penggunaan media sosial yang tinggi tentu saja mencakup berbagai kalangan, termasuk remaja. Berdasarkan data yang dihimpun oleh dailysocial.id (2015) penggunaan media sosial sudah dimulai sejak anak-anak. Kebutuhan awal menggunakan media sosial bagi anak-anak adalah untuk bermain game online dan berlanjut seiring dengan bertambahnya usia. Pada usia 13-18 tahun para anak-anak memasuki usia remaja. Dimana mereka mulai mementingkan dunia pertemanan dan berbagai informasi dalam komunitas. Pada usia remaja, mereka mulai melihat eksistensi dan membutuhkan pengakuan dari lingkungan sekitar, terutama di media sosial. Sehingga tidak jarang pada saat sekarang halaman profil remaja menonjolkan kegiatan seharihari untuk mendukung respon dari teman di media sosial.

Salah satu yang menarik di media sosial saat ini adalah adanya viral challenge. Viral challenge adalah tantangan yang dilakukan oleh seseorang atau kelompok yang dibagikan di media sosial untuk kemudian ditiru tau dicontoh oleh orang/kelompok lain. Biasanya viral challenge dilakukan seseorang dan kemudian menyatakan tantangan untuk teman lainnya. Tidak jarang pula, viral challenge dianggap mengikuti trend untuk mendapatkan respon "kekinian" dari teman-teman di media sosial. Hal ini membuktikan bahwa viral challenge mulai menjadi ajang eksistensi mengikuti hal-hal menantang yang dilakukan bersama.

Keberadaan viral challenge akan berdampak positif apabila yang dijadikan tantangan adalah hal-hal yang bersifat positif seperti berbagi, olahraga serta sifat positif lainnya. Hal yang berbeda ditemui ketika viral challenge banyak yang membahayakan keselamatan dan kesehatan orang yang mengerjakannya. Salah satunya adalah skip challenge atau di media sosial kita bisa melihat \#skipchallenge. Tantangan ini dilakukan dengan menekan dada sekeras mungkin sehingga membuat pingsan serta kejang-kejang dan beberapa menit kemudian akan kembali terbangun. Tindakan seperti saja membahayakan nyawa remaja yang mengikuti tantangan ini, karena bisa saja mereka tidak bagun karena kurangnya asupan oksigen sehingga menyebabkan 
kematian. Tidak hanya itu, banyak lagi viral challenge lainnya yang dapat kita temui di media sosial seperti mengusapkan penghapus sampai tangan berdarah, mengiris tangan dengan silet dan lain sebagainya. Pada tahun 2018 juga terdapat tantangan yang banyak dilakukan remaja di media sosial yaitu Keke Challenge. Tantangan ini dilakukan dengan bernyanyi dan berjoget di jalan diiringi dengan mobil yang sedang berjalan. Bahkan tidak jarang tantangan ini dilakukan di jalan raya yang ramai. Oleh karena itu perlu dibahas mengenai perilaku.

Viral challenge merupakan tantangan yang menjadi viral di media sosial. Tantangan ini mengandung indikasi eksistensi untuk jaringan pertemanan yang ada di media sosial. Namun, pada rentang tahun 2016-2017 ini ada banyak viral challenge yang membahayakan bagi orang yang melakukan tantangan tesebut. Berikut beberapa viral challenge yang beredar di media sosial :

a. Skip Challenge (\#skipchallenge), tantangan ini dilakukan dengan menekan dada sekeras mungkin sampai kejang-kejang dan pingsan. Beberapa saat kemudian orang tersebut akan bangun dan mereka akan tertawa bersama-sama (DetikHealth, 2017).

b. Selfie dari tempat yang berbahaya, tantangan ini dilakukan dengan berfoto di tempat tinggi, rel kereta, hingga dipinggir jalan

c. Om telolet om challenge, tantangan ini dilakukan denga berdiri dipinggir jalan sambil menunggu kendaraan besar dan meneriakan om telolet om untuk mendengarkan suara klakson dari kendaraan tersebut. Tantangan ini bisa dilakukan dengan berdiri dipinggir jalan atau menggunakan kendaraan roda 2 untuk menggiringi bus tersebut.

d. Mengiris tangan dengan membentuk nama teman menggunakan silet, dimana tantangan dilakukan oleh remaja yang sedang patah hati. Untuk membuktikan kegelisahannya menggunakan tantangan ini.

e. Menggosokkan penghapus ke tangan sampai berdarah, tantangan ini digunakan untuk mengukur kekuatan menahan sakit. Penghapus akan terus digosokkan sampai tangan berdarah, semakin banyak darah yang dikeluarkan semakin berhasil melakukan tantangan

Menurut Bates (dalam Greifeneder, 2014) 'Information behaviour is an umbrella term for every human interaction with information'. Perilaku informasi adalah interaksi yang dilakukan manusia dalam mencari dan menggunakan informasi. Perilaku informasi dimulai dari bagaimana seseorang mencari informasi dari berbagai sumber informasi sampai dengan 
menggunakan atau tidaknya informasi yang sudah ditemukan. Dalam pembahasan mengenai perilaku informasi pada media sosial bahwa adanya media sosial akan mempengaruhi perilaku informasi yang meliputi tahapan:

a. Kebutuhan informasi

b. Browsing, monitoring, asking

c. Informasi yang berpeluang memenuhi kebutuhan informasi

d. Information publishing, giving, and sharing

e. Keputusan pengambilan informasi

f. Perilaku informasi sosial dalam komunitas

g. Penggunaan dan evaluasi informasi

Kuhltau (dalam Fisher 2005) menyatakan terdapat 6 langkah yang dilakukan dalam perilaku informasi secara umum yaitu:

1. Initiation, yaitu ketika seseorang mengetahui sejauh mana pengetahuan dan kemampuannya jika melihat informasi

2. Selection, yaitu menyeleksi informasi yang dimiliki memisahkan yang berguna dengan yang tidak.

3. Exploration, yaitu ketika seseorang sudah memutuskan untuk mencari informasi. Tahapan ini dimana seseorang menggali informasi yang ingin diketahui secara mendalam.

4. Formulation, yaitu tahapan menggabungkan informasi yang sudah didapatkan

5. Collection, yaitu mengumpulkan informasi dari berbagai sumber untuk kemudian ditarik kesimpulan.

6. Presentation, yaitu tahapan menggunakan informasi

Tujuan penelitian ini adalah untuk melihat bagaimana perilaku remaja dalam mendapatkan informasi mengenai tantanan viral. Berdasarkan perilaku ini juga nantinya dapat dipetakan bagaimana sebaiknya guru, pustakawan dan orang tua dalam mengawasi remaja ketika mengikuti sebuah tantangan di media sosial. Walaupun pada dasarnya tantangan yang viral dapat digunakan untuk merangsang remaja melakukan hal-hal yang positif. 


\section{METODE}

Populasi dalam penelitian ini adalah remaja berusia 10-18 tahun yang aktif di media sosial. Menurut United Nation (2011) bahwa youth is a period of transition from the dependence of childhood to adulthood's independence. Pernyataan ini juga didukung oleh Kementerian Kesehatan (2014) bahwa remaja berada dalam rentang usia 12-24 tahun yang dibagi dalam 2 tahap masa yaitu remaja awal 12-16 tahun dan remaja akhir 17-24 tahun. Menurut dailysocial.com (2015) mengenai analisis penggunaan media sosial pada usia remaja usia 16-18 tahun remaja sudah aware terhadap update informasi. Berdasarkan hal tersebut, dalam penelitian ini mengambil batas usia antara remaja awal dan remaja akhir 16-18 tahun.

Penelitian ini menggunakan metode survey, dimana dibuat seperangkat pertanyaan yang menggambarkan aspek populasi. Adapun penggunaan metode survey adalah untuk mengidentifikasi kegiatan remaja dalam menanggapi informasi mengenai tantangan yang sedang viral di media sosial. Hal ini untuk menjangkau populasi yang menyebar dan jumlah responden yang banyak. Anggota populasi yang akan dijadikan sampel harus memenuhi kriteria responden, yaitu: rentang usia 16-18 tahun, pengguna aktif media sosial (facebook, twitter, instagram) dan pernah mendapatkan informasi mengenai viral challenge.

\section{HASIL DAN PEMBAHASAN}

Berdasarkan data yang sudah dikumpulkan dapat dideskripsikan profil dari responden yaitu sebagai berikut:

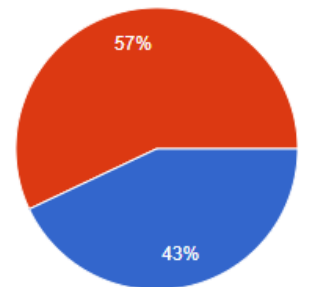

Gambar 1. Identitas Responden

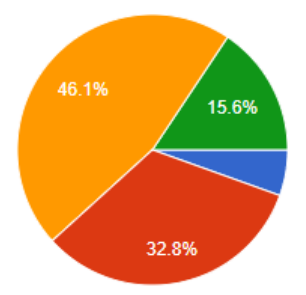

Gambar 2. Usia Responden

Pada penelitian ini penting untuk mendata media sosial apa yang dimiliki remaja. Hal ini dikarenakan media sosial sebagai media bagi remaja dalam mendapatkan informasi mengenai tantangan yang sedang viral. Adapun media sosial yang digunakan remaja adalah sebagai berikut: 
Bibliotech : Jurnal Ilmu Perpustakaan dan Informasi, 3 (1) 2018

Tabel 1. Media Sosial yang digunakan

\begin{tabular}{|l|l|l|}
\hline Jenis Media Sosial & Frekuensi & $\begin{array}{c}\text { Persentase } \\
(\mathbf{\%})\end{array}$ \\
\hline Facebook & 87 & $68 \%$ \\
\hline Twitter & 19 & $14,8 \%$ \\
\hline Instagram & 117 & $91,4 \%$ \\
\hline Line & 100 & $78,1 \%$ \\
\hline Path & 11 & $8,6 \%$ \\
\hline Whats App & 13 & $10,9 \%$ \\
\hline BBM & 1 & $0,8 \%$ \\
\hline Printerest & 2 & $1,6 \%$ \\
\hline
\end{tabular}

Berdasarkan tabel diatas bahwa hampir semua remaja memiliki akun media sosial lebih dari satu. Adapun media sosial terbanyak yang digunakan adalah Instagram, Line dan Facebook. Hal ini membuktikan bahwa remaja saat ini menggunakan media sosial. Kepemilikan akun media sosial ini juga membuktikan bahwa 100\% dari remaja yang menjadi responden penelitian memiliki smartphone, seperti tabel dibawah ini.

Tabel 2. Kepemilikan smartphone

\begin{tabular}{|c|c|c|}
\hline $\begin{array}{c}\text { Kepemilikan } \\
\text { smartphone }\end{array}$ & Frekuensi & $\begin{array}{c}\text { Persentase } \\
(\mathbf{\%})\end{array}$ \\
\hline Ya & 128 & $100 \%$ \\
\hline Tidak & 0 & $0 \%$ \\
\hline Total & 128 & $100 \%$ \\
\hline
\end{tabular}

Kepemilikan smartphone bagi remaja membuktikan bahwa remaja sangat dekat dengan media sosial. Berdasarkan hasil penelitian didapatkan bahwa $73 \%$ remaja mengakses media sosial lebih dari 8x dalam sehari, seperti tabel dibawah ini:

Tabel 3. Frekuensi Akses Media Sosial

\begin{tabular}{|c|c|c|}
\hline Frekuensi & Jumlah & Persentase(\%) \\
\hline$<\mathbf{2}$ kali & 3 & $2,4 \%$ \\
\hline 3 - 5 kali & 12 & $9,4 \%$ \\
\hline 6 - 8 kali & 19 & $14,8 \%$ \\
\hline$>\mathbf{8}$ kali & 94 & $73,4 \%$ \\
\hline Total & 128 & $100 \%$ \\
\hline
\end{tabular}

Inisiasi merupakan kegiatan menganalisis kebutuhan informasi. Tindakan menganalisis kebutuhan informasi merupakan kegiatan awal dalam melihat perilaku informasi. Pada penelitian ini adapun gambaran sejauh mana kegiatan inisiasi ini dilakukan adalah sebagai berikut: 
Tabel 4. Inisiasi

\begin{tabular}{|l|l|l|}
\hline \multicolumn{1}{|c|}{ Keterangan } & Frekuensi & Persentase \\
\hline $\begin{array}{l}\text { Tantangan yang sedang viral selalu muncul di halaman } \\
\text { media sosial saya }\end{array}$ & 71 & $55,5 \%$ \\
\hline $\begin{array}{l}\text { Saya mencari tantangan yang sedang viral di media } \\
\text { sosial atas keinginan saya sendiri }\end{array}$ & 73 & $57 \%$ \\
\hline $\begin{array}{l}\text { Saya mencari tantangan yang sedang viral di media } \\
\text { sosial berdasarkan postingan teman sebelumnya }\end{array}$ & 83 & $65 \%$ \\
\hline $\begin{array}{l}\text { Saya mencari banyak tantangan yang sedang viral di } \\
\text { media sosial secara spontan }\end{array}$ & 69 & $54 \%$ \\
\hline $\begin{array}{l}\text { Saya mencari informasi mengenai tantangan viral } \\
\text { dengan mengetikkan kata kunci }\end{array}$ & 71 & $55,5 \%$ \\
\hline
\end{tabular}

Berdasarkan data diatas, responden mengenal kebutuhan informasi mereka dimulai dari banyaknya informasi mengenai tantangan viral yang muncul di halaman utama media sosial mereka. Kemunculan informasi itu dimulai karena (1) memang karena tantangan itu sangat banyak dilakukan teman-teman media sosialnya sehingga muncul sebagai highlight; (2) temanteman media sosial yang mereka kenal melakukan tantangan tersebut sehingga mereka terpancing untuk mencari informasi tersebut.

Seleksi merupakan lanjutan dari inisiasi. Setelah menentukan kebutuhan informasi dilakukan proses pemilihan informasi secara selektif. Informasi yang dicari menandakan informasi yang dibutuhkan atau disukai. Pada tahapan ini, seseorang akan mulai merasa perlu melakukan pencarian informasi. Berdasarkan hasil penelitian, perilaku seleksi remaja terhadap informasi tantangan viral di media sosial adalah sebagai berikut:

Tabel 5. Seleksi

\begin{tabular}{|l|l|l|}
\hline \multicolumn{1}{|c|}{ Keterangan } & Frekuensi & Persentase \\
\hline $\begin{array}{l}\text { Saya menelusur siapa saja teman saya yang } \\
\text { mengikuti tantangan viral }\end{array}$ & 84 & $66 \%$ \\
\hline $\begin{array}{l}\text { Saya biasanya menanyakan kepada teman di media } \\
\text { sosial saya mengenai tantangan yang sedang viral di } \\
\text { media sosial }\end{array}$ & 84 & $66 \%$ \\
\hline
\end{tabular}

Para remaja juga melakukan proses seleksi informasi mengenai tantangan yang sedang viral di media sosial. Adapun kegiatan seleksi yang mereka lakukan mulai dari menelusur informasi mengenai siapa saja teman yang sudah mnegikuti tantangan tersebut kemudian menanyakan kepada temannya secara langsung. Tahap ekplorasi merupakan tahapan menyatakan dengan tepat kebutuhan informasi. Pada tahapan ini juga proses penyeleksian lebih tersaring daripada proses seleksi. Pada tahapan eksplorasi para remaja memilih satu tantangan 
kemudian digali secara mendalam. Dalam proses penggalian lebih dalam itu, mereka melakukan seleksi informasi mengenai tantangan tersebut. Adapun tahap eksplorasi remaja terhadap informasi tantangan viral di media sosial adalah sebagai berikut:

Tabel 6. Eksplorasi

\begin{tabular}{|l|l|l|}
\hline Keterangan & Frekuensi & Persentase \\
\hline $\begin{array}{l}\text { Saya biasanya memilih informasi tertentu mengenai } \\
\text { tantangan yang sedang viral di media sosial }\end{array}$ & $\mathbf{6 8}$ & \\
\hline $\begin{array}{l}\text { Saya biasanya menyeleksi berbagai informasi } \\
\text { mengenai tantangan yang sedang viral di media } \\
\text { sosial }\end{array}$ & $\mathbf{5 8 \%}$ \\
\hline
\end{tabular}

Tahap formulasi merupakan tahapan penggabungan berbagai informasi menjadi satu informasi yang utuh. Pada tahapan ini, seseorang menanyakan sebuah informasi dari berbagai sumber. Pada penelitian ini, tahapan formulasi dapat dilihat dari alat dan bahan serta cara melakukan tantangan tersebut. Artinya sumber informasi bisa dari media sosial sendiri dan menanyakan secara langsung (melalui interaksi langsung). Berdasarkan hasil penelitian didapatkan bahwa:

Tabel 7. Formulasi

\begin{tabular}{|l|l|l|}
\hline Keterangan & Frekuensi & Persentase \\
\hline $\begin{array}{l}\text { Saya mencari tau bagaimana melakukan suatu } \\
\text { tantangan di media sosial dengan menggunakan kata } \\
\text { kunci }\end{array}$ & 72 & $\mathbf{5 6 \%}$ \\
\hline $\begin{array}{l}\text { Saya menanyakan ke teman di media sosial saya } \\
\text { bagaimana melakukan suatu tantangan di media sosial }\end{array}$ & $\mathbf{7 0}$ & $\mathbf{5 5 \%}$ \\
\hline
\end{tabular}

Pada tahapan formulasi, remaja sudah memilih satu informasi yang menjadi fokus untuk digali. Misalnya responden sudah menentukan memilih tantangan makan mie pedas, maka mereka mulai mencari jenis mie, bagaimana tingkat level kepedasan dan hastag apa saja yang digunakan dalam proses unggahnya nanti.

Tahapan koleksi merupakan tahapan interaksi antara orang yang membutuhkan informasi dengan sistem (disini media sosial). Tahapan koleksi juga merupakan tahapan memastikan apakah semua informasi yang ada sudah menjawab kebutuhan informasi mereka. Berdasarkan hasil penelitian, tahapan koleksi dilakukan dengan cara sebagai berikut: 
Tabel 8. Koleksi

\begin{tabular}{|l|c|c|}
\hline \multicolumn{1}{|c|}{ Keterangan } & Frekuensi & Persentase \\
\hline $\begin{array}{l}\text { Saya mengikuti media sosial (facebook, twitter, ig dsb) } \\
\text { yang kontennya mengikuti suatu tantangan di media } \\
\text { sosial }\end{array}$ & $\mathbf{7 0}$ & $\mathbf{5 5 \%}$ \\
\hline $\begin{array}{l}\text { Saya mengumpulkan berbagai informasi terkait satu } \\
\text { tantangan yang sedang viral di media sosial }\end{array}$ & $\mathbf{6 9}$ & $\mathbf{5 3 , 9 \%}$ \\
\hline
\end{tabular}

Pada tahapan ini, remaja mengikuti media sosial yang berisikan konten sesuai dengan tantangan yang disukai. Hal ini dapat dilihat pada table diatas, dimana setengah dari responden atau $34,4 \%$ setuju dan $20,3 \%$ sangat setuju kalau mereka mengikuti media sosial yang berisi konten terkait tantangan tersebut.

Tahapan presentasi merupakan tahapan akhir, dimana seseorang memutuskan untuk menggunakan informasi yang sudah dikumpulkan atau tidak. Pada tahapan ini akan dilihat bagaimana kepuasan seseorang terhadap informasi yang sudah dikumpulkan. Pada penelitian tahapan presentasi berkaitan dengan keputusan para remaja untuk melakukan tantangan sesuai dengan informasi yang sudah mereka kumpulkan. Selain itu juga akan dilihat kepuasan mereka terhadap informasi yang sudah dikumpulkan. Adapun hasil penelitiannya adalah sebagai berikut:

Tabel 9. Presentasi

\begin{tabular}{|l|l|l|}
\hline \multicolumn{1}{|c|}{ Keterangan } & Frekuensi & Persentase \\
\hline $\begin{array}{l}\text { Saya mengikuti tantangan viral agar dikatakan } \\
\text { eksis }\end{array}$ & 70 & $\mathbf{5 4 , 6 \%}$ \\
\hline $\begin{array}{l}\text { Saya mengikuti tantangan yang sedang viral di } \\
\text { media sosial walaupun itu membahayakan }\end{array}$ & 12 & $\mathbf{9 , 4 \%}$ \\
\hline
\end{tabular}

Berdasarkan Tabel 9, kegiatan presentasi para remaja mereka memilih untuk melakukan tantangan yang menurut mereka dengan tujuan bersenang-senang dengan teman-temannya. Mereka tidak melakukan tantangan yang secara nyata membahayakan mereka seperti skip challenge dan gosok penghapus ke tangan sampai berdarah. Namun ada beberapa tantangan yang akan menganggu kesehatan seperti makan ayam atau mie sangat pedas. Untuk tantangan lainnya masih dapat dikatakan aman hanya bertujuan bersenang-senang dengan temantemannya. 
Bibliotech : Jurnal Ilmu Perpustakaan dan Informasi, 3 (1) 2018

Tabel 10. Tantangan Viral

\begin{tabular}{|l|c|c|}
\hline \multicolumn{1}{|c|}{ Jenis Tantangan Viral } & Frekuensi & $\begin{array}{c}\text { Persentase } \\
(\%)\end{array}$ \\
\hline Om telolet om & 36 & $28,1 \%$ \\
\hline Skip Challenge & 3 & $\mathbf{2 , 3 \%}$ \\
\hline $\begin{array}{l}\text { Gosok penghapus sampai } \\
\text { berdarah }\end{array}$ & 1 & $\mathbf{0 , 8 \%}$ \\
\hline Manequinne Challenge & 45 & $\mathbf{3 5 , 2 \%}$ \\
\hline Musically Challenge & 17 & $\mathbf{1 3 , 3 \%}$ \\
\hline $\begin{array}{l}\text { Samyang/mie pedas } \\
\text { Challenge }\end{array}$ & 32 & $\mathbf{2 5 \%}$ \\
\hline Sayap ayam pedas & $\mathbf{4 0}$ & $\mathbf{3 1 , 3 \%}$ \\
\hline $\begin{array}{l}\text { Selfie di pinggir jalan atau } \\
\text { tempat berbahaya }\end{array}$ & $\mathbf{6}$ & $\mathbf{4 , 7 \%}$ \\
\hline Tiktok & $\mathbf{3}$ & $\mathbf{2 , 3 \%}$ \\
\hline Lainnya & \multicolumn{2}{|c|}{} \\
\hline
\end{tabular}

Tabel yang menjelaskan mengenai keputusan menggunakan informasi mengenai tantangan di media sosial bagi remaja. Kesimpulan dari tahapan presentasi ini adalah para remaja menyukai informasi mengenai tantangan yang sedang viral, namun untuk melakukan tantangan tersebut mereka menyeleksi informasi agar tantangan yang mereka lakukan tidak hanya sebagai eksistensi diri namun juga memperhatikan kesehatan dan keselamatan.

\section{KESIMPULAN}

Secara umum terdapat tiga tantangan viral yang dikenal oleh remaja (1) tantangan yang dilakukan secara bersama untuk tujuan bersenang-senang, seperti mannequin challenge, tiktok, musically (2) tantangan yang jika dilakukan secara umum memang berpengaruh kesehatan seperti makan mie pedas, makan sayap ayam pedas (3) tantangan yang membahayakan keselamatan selfie di pinggir jalan atau tempat berbahaya dan om telolet om.

\section{DAFTAR PUSTAKA}

Dailysocial.id. (2015). Penggunaan media sosia di Indonesia mulai tersegmentasi berdasarkan kebutuhan. Available from https://dailysocial.id/post/penggunaan-media-sosial-diindonesia-mulai-tersegmentasi-berdasarkan-kebutuhan (25 April 2017)

detikHealth.com. (2017). Aneka tantangan di medsos ini bisa bikin remaja celaka. Available from https://health.detik.com/read/2017/03/03/090230/3437005/763/2/aneka-tantangandi-medsos-ini-bisa-bikin-remaja-celaka (25 April 2017) 
Bibliotech : Jurnal Ilmu Perpustakaan dan Informasi, 3 (1) 2018

Fisher, K.E. (2005) Theories of Information Behavior. ASIST: New Jersey

Greifeneder, E. (2014) 'Trends in information behaviour research', Proceedings of ISIC: the information behaviour conference, vol.19, no.4, December 2014, akses 15 Maret 2017 http://www.informationr.net/ir/19-4/isic/isic13.html\#.WMs6ZaKwrIU

Kaplan, A.M \& Haenlein, M. (2010). 'Users of the world, unite! The challenges and opportunities of social media' Business Horizons, vol (53) pp. 59-68. Available from https://www.slideshare.net/Twittercrisis/kaplan-and-haenlein-2010-social-media April 2017

Kementerian Kesehatan. (2014) Kesehatan Remaja. Available from http://www.depkes.go.id/dpwnoad.php?file=download/pusdatin/infodatin/infodatin\%20re produksi\%20remaja-ed.pdf (24 April 2017)

Kompas.com (2016). Pengguna internet Indonesia mencapai 132 Juta. Available from http://tekno.kompas.com/read/2016/10/24/15064727/2016.pengguna.internet.di.indonesia .capai.132.juta. (25 April 2017)

United Nation. (2011). Definiton of youth. Available from http://www.unhabitat.org/pmss/listItemDetails.aspx?publicationID=3393 (25 April 2017) 
Bibliotech : Jurnal Ilmu Perpustakaan dan Informasi, 3 (1) 2018 